\title{
The Specificity of the Anionic Requirement for Iron Oxidation by Thiobacillus ferrooxidans
}

\author{
By NORMAN LAZAROFF \\ Department of Biological Sciences, State University of New York, \\ Binghamton, New York I $390 \mathrm{I}$, U.S.A.
}

(Received 22 December 1976; revised I March 1977)

\begin{abstract}
The anionic requirement for the oxidation of ferrous ions by suspensions of Thiobacillus ferrooxidans was satisfied by selenate as well as sulphate. Selenate was toxic to the organism and suppressed growth in ferrous iron media, even in the presence of high concentrations of sulphate. After treatment with dilute hydrochloric acid at $0{ }^{\circ} \mathrm{C}, T$. ferrooxidans, which specifically required $\mathrm{SO}_{4}{ }^{2-}$ or $\mathrm{SeO}_{4}{ }^{2-}$ for iron oxidation, showed no activity in response to 12 other anions tested. However, after the introduction of $\mathrm{SO}_{4}{ }^{2-}$ or $\mathrm{SeO}_{4}{ }^{2-}$, addition of anions such as $\mathrm{TeO}_{4}{ }^{2-}, \mathrm{WO}_{4}{ }^{2-}, \mathrm{AsO}_{4}{ }^{3-}$ or $\mathrm{PO}_{4}{ }^{3-}$ further enhanced the rate of iron oxidation. Under these conditions, $\mathrm{Cl}^{-}, \mathrm{B}_{4} \mathrm{O}_{7}{ }^{2-}$ and $\mathrm{ClO}_{3}{ }^{-}$had no significant effect at low concentration, whereas $\mathrm{Br}^{-}, \mathrm{NO}_{3}{ }^{-}$and $\mathrm{MoO}_{4}{ }^{2-}$ were inhibitory. These observations distinguish between a specific and a non-specific anionic requirement for the oxidation of ferrous ions by $T$. ferrooxidans. The specific requirement is satisfied only through the uptake of $\mathrm{SO}_{4}{ }^{2-}$ or $\mathrm{SeO}_{4}{ }^{2-}$ by the bacteria. The non-specific requirement is satisfied by any one of several anions, including $\mathrm{SO}_{4}{ }^{2-}$ and $\mathrm{SeO}_{4}{ }^{2-}$, which are presumed to act as ligands for iron in solution.
\end{abstract}

\section{INTRODUCTION}

Inorganic anions such as $\mathrm{Cl}^{-}$and $\mathrm{NO}_{3}$ inhibit iron oxidation as well as growth of the autotrophic bacterium Thiobacillus ferrooxidans (Lazaroff, 1963; Razzell \& Trussel, 1963; Schnaitman, Korczynski \& Lundgren, I969; Tuovinen, Niemella \& Gyllenberg, I97I). To account for these effects, it has been proposed that sulphate ions are required for autotrophic iron oxidation and that the inhibitory anions compete with sulphate for some metabolic site essential for iron oxidation. The principal support for this hypothesis comes from the observation that sulphate ions stimulate the oxidation of ferrous chloride solutions by suspensions of $T$. ferrooxidans (Lazaroff, 1963; Tuovinen, Kelley \& Nicholas, 1975). The stimulation of iron oxidation by sulphate ions is manifested by increases in both the rate of oxygen uptake and the rate of ferric ion formation (Steiner \& Lazaroff, 1974).

The concept of a sulphate requirement for iron oxidation fits the observed facts and seems the simplest explanation for sulphate reversal of the anionic inhibition of ferrous ion oxidation. Indeed, Dugan \& Lundgren (1965) demonstrated a rapid uptake of sulphate by cell envelopes of $T$. ferrooxidans during iron oxidation. In their model of the oxidation of ferrous ions, occurring at the periphery of the cell envelope, the combination of sulphate, phosphate and ferrous ions is an initial step. However, the mechanism by which sulphate effects ferrous ion oxidation still requires elucidation, and relevant to this question is whether $\mathrm{SO}_{4}{ }^{2-}$ is a specific requirement for $\mathrm{Fe}^{2+}$ oxidation or whether other anions can substitute for it.

In studying the specificity of the sulphate requirement, selenate was of special interest as it is chemically similar to sulphate, can substitute for sulphate in its assimilation and become incorporated into selenium analogues of the naturally occurring sulphur amino 
acids (Stadtman, 1974). Sulphate-selenate interchangeability also occurs in the inhibition of chloroplast photophosphorylation (Pick \& Avron, 1973): in this case, selenate and sulphate are almost equally effective in competing with the phosphate required.

\section{METHODS}

Organism and growth. Thiobacillus ferrooxidans, Leathen strain, was cultivated routinely in the $9 \mathrm{~K}$ medium of Silverman \& Lundgren (1959). Modifications of the $9 \mathrm{~K}$ medium with $\mathrm{FeCl}_{2}$ (and $\mathrm{HCl}$ ) instead of $\mathrm{FeSO}_{4}$ (and $\mathrm{H}_{2} \mathrm{SO}_{4}$ ), or with all $\mathrm{SO}_{4}{ }^{2-}$ replaced by $\mathrm{Cl}^{-}$, were used to test for the effect of sulphate and selenate additions on the growth of $T$. ferrooxidans. The $9 \mathrm{~K}$ medium had the following composition: $23 \mathrm{mM}-\left(\mathrm{NH}_{4}\right)_{2}-$

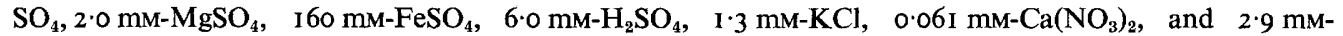
$\mathrm{K}_{2} \mathrm{HPO}_{4}$. Where appropriate, sulphate salts were replaced by chlorides to give the same concentrations of the required cations $\left(\mathrm{NH}_{4}{ }^{+}, \mathrm{Mg}^{2+}, \mathrm{Fe}^{2+}, \mathrm{H}^{+}\right)$.

All components of culture media, with the exception of the ferrous iron source, were sterilized by autoclaving at $120^{\circ} \mathrm{C}$ for $15 \mathrm{~min}$. Solutions of iron salts for the culture media were made up just before use at $0.37 \mathrm{M}$ and acidified with the appropriate acid to $\mathrm{pH} 2.5$. Where required, the iron solutions were sterilized by filtration through membrane or sintered-glass filters before combining with the acidified sterile basal medium. Growth experiments were usually carried out with continuous shaking in $250 \mathrm{ml}$ Erlenmeyer flasks containing $100 \mathrm{ml}$ medium, but to obtain large quantities of bacteria cultures were grown in 201 bottles containing to 1 unsterile medium using forced aeration. All cultures were grown at room temperature.

Suspensions for iron oxidation experiments were prepared by filtering a culture from an aerated bottle through Whatman no. I paper. The residues on the filter paper were washed with cold $\mathrm{I} \cdot 6 \mathrm{~mm}-\mathrm{H}_{2} \mathrm{SO}_{4}$ and the washings were combined with the first filtrate. The bacteria were collected by centrifuging the filtrate either through a Sharples continuous flow centrifuge or at $30000 \mathrm{~g}$ for $20 \mathrm{~min}$, and then resuspended in Io $\mathrm{mM}_{\mathrm{M}} \mathrm{H}_{2} \mathrm{SO}_{4}$. Sedimentation and resuspension were repeated to remove oxidized iron particles.

Measurement of ferric ion formation. Ferric ions were initially determined by a modification of the thiocyanate method (Kolthoff et al., 1969). Samples were removed from reaction mixtures, and each was mixed with an equal volume of $6 \mathrm{M}-\mathrm{HCl}$ to stop oxidation, diluted to a suitable volume with water and a portion containing from 2 to $25 \mu \mathrm{g} \mathrm{Fe}^{3+}$ was mixed with $0.5 \mathrm{ml} 6 \mathrm{M}-\mathrm{HCl}$ and $0.5 \mathrm{ml} 3 \mathrm{M}-\mathrm{KSCN}$. The volume was brought to $5.0 \mathrm{ml}$ and $E_{490}$ was determined. Standards were prepared from solutions of $\mathrm{NH}_{4} \mathrm{Fe}\left(\mathrm{SO}_{4}\right)_{2} \cdot 12 \mathrm{H}_{2} \mathrm{O}$. Additional measurements of the rates of $\mathrm{Fe}^{3+}$ formation were carried out continuously in a Cary model 15 recording spectrophotometer at $304 \mathrm{~nm}$, according to the method of Steiner \& Lazaroff (1974).

Measurement of oxygen uptake. Oxygen uptake of bacteria oxidizing iron was measured manometrically in Warburg flasks. The usual protocol involved placing $0.2 \mathrm{ml}$ of an acidified suspension of $T$. ferrooxidans in the sidearm, and the substrate and any other additions, to $x .6 \mathrm{ml}$, in the main chamber of the flask. The centre well received $0.2 \mathrm{ml}$ of $20 \%(\mathrm{w} / \mathrm{v}) \mathrm{KOH}$ and a filter paper wick. After equilibration and mixing, measurements were made conventionally at $28{ }^{\circ} \mathrm{C}$. Specific activities were estimated on the basis of total cell counts determined with a Petroff-Hauser counting chamber and a phase contrast microscope.

\section{RESULTS}

\section{Effect of anions on oxygen uptake during iron oxidation}

Bacteria grown in $\mathrm{FeSO}_{4}$ medium then washed and suspended in $\mathrm{I} \cdot 6 \mathrm{~mm}-\mathrm{H}_{2} \mathrm{SO}_{4}$ exhibited a slow uptake of oxygen in $\mathrm{FeCl}_{2}$ solutions. The rate of oxygen uptake was markedly increased by adding either $\mathrm{SO}_{4}{ }^{2-}$ or $\mathrm{SeO}_{4}{ }^{2-}$, indicating that either substance can satisfy the anionic requirement for the oxidation of $\mathrm{Fe}^{2+}$. As the anion concentration was increased the rate of oxygen consumption rose to a maximum, and then diminished as the $\mathrm{SO}_{4}{ }^{2-}$ or $\mathrm{SeO}_{4}{ }^{2-}$ concentration exceeded an optimal level (Fig. I $a$ ). In $44 \mathrm{~mm}-\mathrm{Fe}^{2+}$ solutions, the rate of oxygen consumption was maximal when the individual or combined concentrations of $\mathrm{SO}_{4}{ }^{2-}$ and $\mathrm{SeO}_{4}{ }^{2-}$ were about twice the $\mathrm{Fe}^{2+}$ concentration. A similar relationship between $\mathrm{SO}_{4}{ }^{2-}$ concentration and oxygen consumption was observed in the presence of phosphate which further stimulated the rate of oxygen uptake (Fig. I $a$ ). Anions such as $\mathrm{NO}_{3}{ }^{-}$and $\mathrm{Cl}^{-}$ inhibited oxygen uptake due to iron oxidation, but this inhibition was reversed by adding $\mathrm{SO}_{4}{ }^{2-}$ or $\mathrm{SeO}_{4}{ }^{2-}$ (Table I). However the inhibition of oxygen uptake produced by adding $44 \mathrm{mM}-\mathrm{B}_{4} \mathrm{O}_{7}{ }^{2-}$, succinate or acetate (anions which form undissociated acids at $\mathrm{pH}{ }_{2} \cdot 5$ ) was not counteracted by increasing the $\mathrm{SO}_{4}{ }^{2-}$ concentration. 
Table I. Effect of various anions on oxygen uptake by T. ferrooxidans in $\mathrm{FeSO}_{4}$ solutions

Reaction mixtures contained $44 \mathrm{~mm}-\mathrm{FeSO}_{4}, \mathrm{I}_{5} \mathrm{~mm}-\mathrm{KH}_{2} \mathrm{PO}_{4}$ and the anions indicated (as sodium salts). All solutions were adjusted to $\mathrm{pH} 2.5$ with $\mathrm{H}_{2} \mathrm{SO}_{4}$. Each result is expressed as a percentage of the control rate determined for a basal solution to which a portion of the same bacterial suspension was added at the same time.

Additions

None

I $30 \mathrm{mM}-\mathrm{Cl}^{-}$

$130 \mathrm{mM}^{-\mathrm{Cl}^{-}}, 44 \mathrm{mM}_{-} \mathrm{SeO}_{4}{ }^{2-}$

$44 \mathrm{~mm}^{-\mathrm{NO}_{3}}{ }^{-}$

$44 \mathrm{~mm}^{-\mathrm{NO}_{3}-}, 44 \mathrm{~mm}^{-\mathrm{SeO}_{4}}{ }^{2-}$

$44 \mathrm{~mm}^{-\mathrm{NO}_{3}}{ }^{-}, 44 \mathrm{~mm}^{-\mathrm{SO}_{4}}{ }^{2-}$
Oxygen uptake Percentage of $\left(\mu 1 \min ^{-1}\right) \quad$ control

$\begin{array}{lc}I \cdot 3 I & - \\ 0.6 I & 46 \cdot 6 \\ 0.79 & 60.3 \\ 0.24 & 18 \cdot 3 \\ 0.46 & 35 \cdot I \\ 0.46 & 35 \cdot I\end{array}$

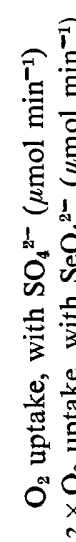

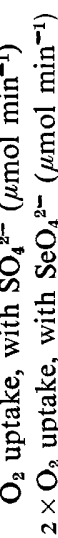
0.15
0.12
0.09
0.06
0
0 (a)

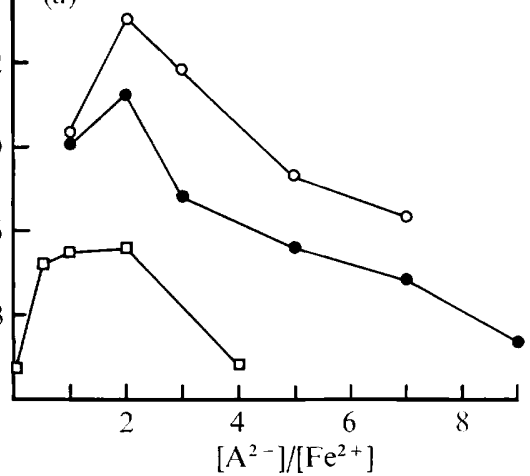

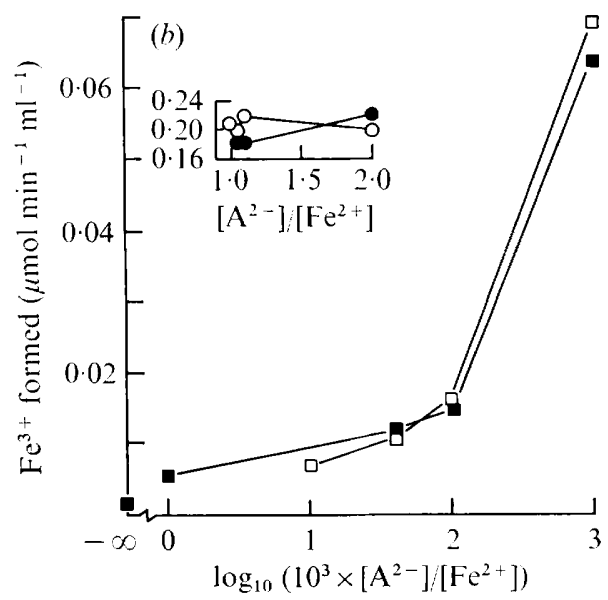

Fig. I. Effect of sulphate and selenate on the rates of oxygen uptake and $\mathrm{Fe}^{3+}$ formation by $T$. ferrooxidans oxidizing $\mathrm{Fe}^{2+}$.

(a) Oxygen uptake. This was determined manometrically, see Methods, with $\mathrm{I} \cdot 6 \mathrm{ml} \mathrm{Fe} \mathrm{F}^{2+}$ substrate in the main chamber and $0.2 \mathrm{ml}$ suspension $\left(3.8 \times 10^{9}\right.$ bacteria $\left.\mathrm{ml}^{-1}\right)$ in the sidearm. Substrates were: (O) $44 \mathrm{~mm}-\mathrm{FeSO}_{4}, 6 \cdot 7 \mathrm{mM}-\mathrm{KH}_{2} \mathrm{PO}_{4}$ plus increments of $\mathrm{Na}_{2} \mathrm{SO}_{4}$; (O) $44 \mathrm{mM}-\mathrm{FeSO}_{4}$ plus increments of $\mathrm{Na}_{2} \mathrm{SO}_{4} ;(\square) 44 \mathrm{~mm}-\mathrm{FeCl}_{2}$ plus increments of $\mathrm{Na}_{2} \mathrm{SeO}_{4}$. The rates of oxygen uptake were linear for at least the first $20 \mathrm{~min}$.

(b) $\mathrm{Fe}^{3+}$ formation. $\mathrm{I} \times 10^{9}$ bacteria were added to $50 \mathrm{ml}$ Erlenmeyer flasks containing $0 \cdot \mathrm{I} \mathrm{M}-\mathrm{Fe}^{2+}$ substrate, $17 \mathrm{~mm}-\mathrm{KH}_{2} \mathrm{PO}_{4}$ plus increments of $\mathrm{Na}_{2} \mathrm{SO}_{4}$ or $\mathrm{Na}_{2} \mathrm{SeO}_{4}$ in a total volume of $10 \mathrm{ml}$. The pH was adjusted to $2 \cdot 5$ with $\mathrm{HCl}$ or $\mathrm{H}_{2} \mathrm{SO}_{4}$ as appropriate. Temperature was maintained at $30{ }^{\circ} \mathrm{C}$. All flasks contained approximately $0.016 \mathrm{~mm}$ additional $\mathrm{H}_{2} \mathrm{SO}_{4}$ introduced with the bacterial

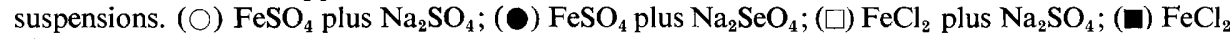
plus $\mathrm{Na}_{2} \mathrm{SeO}_{4}$.

\section{Effects of sulphate and selenate on growth}

Growth of $T$. ferrooxidans was not detected after several weeks incubation in a modified $9 \mathrm{~K}$ medium in which all $\mathrm{SO}_{4}{ }^{2-}$ had been replaced by $\mathrm{Cl}^{-}$, despite the introduction of small amounts of $\mathrm{SO}_{4}{ }^{2-}$ with the inoculum. In $9 \mathrm{~K}$ medium in which only $\mathrm{FeSO}_{4}$ had been replaced by $\mathrm{FeCl}_{2}$ (25 $\mathrm{mM} \mathrm{SO}_{4}{ }^{2-}$ instead of I9I mM) slow growth and visible oxidation of iron were observed I I days after inoculation, while control flasks with $\mathrm{FeSO}_{4}$ showed growth and oxidation by 3 days. Bacteria from either $\mathrm{FeCl}_{2}$ medium or $\mathrm{FeSO}_{4}$ medium failed to grow after subculture in $\mathrm{FeCl}_{2}$ or $50 \% \mathrm{FeCl}_{2} / 50 \% \mathrm{FeSO}_{4}$ media unless large inocula ( $>\mathrm{I}^{6}$ bacteria) were used, indicating that slow growth in media containing low concentrations of $\mathrm{SO}_{4}{ }^{2-}$ does not select for organisms which do not require $\mathrm{SO}_{4}{ }^{2-}$ for oxidizing $\mathrm{Fe}^{2+}$. 
Table 2. Effect of selenate on growth of $T$. ferrooxidans in media containing $\mathrm{FeSO}_{4}$ or $\mathrm{FeCl}_{2}$

\begin{tabular}{|c|c|c|c|c|c|c|}
\hline \multirow[b]{2}{*}{$\begin{array}{l}\text { Additions to basal medium* } \\
\text { (Na salts) }\end{array}$} & \multicolumn{2}{|c|}{$\begin{array}{l}\text { After } 4 \text { days in } \\
0.16 \mathrm{M}-\mathrm{FeSO}_{4}\end{array}$} & \multicolumn{2}{|c|}{$\begin{array}{l}\text { After } 4 \text { days in } \\
0 . \mathrm{I}_{\mathrm{M}-\mathrm{FeCl}_{2}}\end{array}$} & \multicolumn{2}{|c|}{$\begin{array}{l}\text { After } 8 \text { days in } \\
0 \cdot \mathrm{I}_{\mathrm{M}-\mathrm{FeCl}_{2}}\end{array}$} \\
\hline & $\begin{array}{c}\mathrm{IO}^{-6} \times \mathrm{no} \text {. } \\
\text { of bacteria } \\
\mathrm{ml}^{-1}\end{array}$ & $\begin{array}{c}\mathrm{Fe}^{3+} \\
\text { produced } \\
\left(\mathrm{mg} \mathrm{ml}^{-1}\right)\end{array}$ & $\begin{array}{c}10^{-6} \times \text { no. } \\
\text { of bacteria } \\
\mathrm{ml}^{-1}\end{array}$ & $\begin{array}{c}\mathrm{Fe}^{3+} \\
\text { produced } \\
\left(\mathrm{mg} \mathrm{ml}^{-1}\right)\end{array}$ & $\begin{array}{l}10^{-6} \times \text { no. } \\
\text { of bacteria } \\
\quad \mathrm{ml}^{-1}\end{array}$ & $\begin{array}{c}\mathrm{Fe}^{3+} \\
\text { produced } \\
\left(\mathrm{mg} \mathrm{ml}^{-1}\right)\end{array}$ \\
\hline None & $5 \cdot 2$ & $7 \cdot 13$ & 0.0 & 0.23 & $0.0 \dagger$ & 0.88 \\
\hline $\begin{array}{l}\text { O. I } \mathrm{mM}^{-S_{e O}}{ }_{4}{ }^{2-} \\
\text { I } \mathrm{mM}_{-}-\mathrm{SeO}_{4}{ }^{2-} \\
5 \mathrm{mM}_{-} \mathrm{SeO}_{4}{ }^{2-} \\
\text { IO } \mathrm{mM}_{-} \mathrm{SeO}_{4}{ }^{2-}\end{array}$ & $\begin{array}{l}4.3 \\
0.95 \\
0.0 \\
0.0\end{array}$ & $\begin{array}{l}6 \cdot 13 \\
5 \cdot 70 \\
0 \cdot 28 \\
\text { ND }\end{array}$ & $\begin{array}{l}0.0 \\
0.0 \\
0.0 \\
0.0\end{array}$ & $\begin{array}{c}0.05 \\
0.06 \\
0.07 \\
\text { ND }\end{array}$ & $\begin{array}{l}\mathbf{I} \cdot 8 \\
0.0 \\
0.0 \\
0.0\end{array}$ & $\begin{array}{l}I \cdot 77 \\
0.35 \\
0.48 \\
\text { ND }\end{array}$ \\
\hline 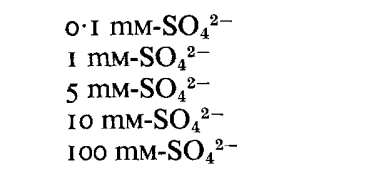 & $\begin{array}{r}4 \cdot 4 \\
5 \cdot 3 \\
5 \cdot 3 \\
\text { II } \cdot 7 \\
\text { II } \cdot 2\end{array}$ & $\begin{array}{l}6 \cdot 33 \\
5 \cdot 8 \\
5 \cdot 8 \\
5 \cdot 7 \\
6 \cdot 2\end{array}$ & $\begin{array}{l}0.0 \\
0.0 \\
0.0 \\
I \cdot 5 \\
0.7\end{array}$ & $\begin{array}{l}0.18 \\
0.09 \\
0.11 \\
2.85 \\
2.02\end{array}$ & $\begin{array}{l}2 \cdot 8 \\
3 \cdot 0 \\
1 \cdot 3 \\
\text { ND } \\
\text { ND }\end{array}$ & $\begin{array}{l}2 \cdot 7 \\
4 \cdot 3 \\
I \cdot 0 \\
\text { ND } \\
\text { ND }\end{array}$ \\
\hline
\end{tabular}

Selenate inhibited the growth of $T$. ferrooxidans in $\mathrm{FeCl}_{2}$ and $\mathrm{FeSO}_{4}$ media (Table 2). After 8 days incubation, only the lowest concentration of $\mathrm{SeO}_{4}{ }^{2-}(\mathrm{O} \cdot \mathrm{I} \mathrm{mM})$ permitted growth in $\mathrm{FeCl}_{2}$ medium. At I mM, selenate inhibited growth in $\mathrm{FeSO}_{4}$ medium containing $190 \mathrm{~mm}-$ $\mathrm{SO}_{4}{ }^{2-}$. Since $\mathrm{SO}_{4}{ }^{2-}$ and $\mathrm{SeO}_{4}{ }^{2-}$ affect iron oxidation similarly (Fig. $\mathrm{I} b$ ), the inhibition of growth by selenate in $\mathrm{Fe}^{2+}$ media is probably not related to the process of iron oxidation but results from some biochemical process in which the exclusion or replacement of $\mathrm{SO}_{4}{ }^{2-}$ by $\mathrm{SeO}_{4}{ }^{2-}$ is injurious.

\section{Effects of anions on $\mathrm{Fe}^{3+}$ formation}

The suspensions of $T$. ferrooxidans grown in $\mathrm{FeSO}_{4}$ medium which were routinely used contained sufficient $\mathrm{SO}_{4}{ }^{2-}$ to allow a slow uptake of oxygen and oxidation of $\mathrm{Fe}^{2+}$ in $\mathrm{FeCl}_{2}$ solutions. Increased rates of oxidation were obtained on addition of $\mathrm{SO}_{4}{ }^{2-}$ or $\mathrm{SeO}_{4}{ }^{2-}$ (Fig. $\mathrm{I} b$ ). Therefore, the oxidation of $\mathrm{Fe}^{2+}$ in chloride solutions would presumably be diminished or eliminated by washing the bacteria to remove $\mathrm{SO}_{4}{ }^{2-}$. When the bacteria were washed by sedimentation and resuspension in $\mathrm{HCl}$ instead of $\mathrm{H}_{2} \mathrm{SO}_{4}$ at room temperature, much of the iron-oxidizing activity for both $\mathrm{FeSO}_{4}$ and $\mathrm{FeCl}_{2}$ was lost (Fig. 2a). Activity was not restored by resuspending bacteria in $\mathrm{I} \cdot 6 \mathrm{~mm}-\mathrm{H}_{2} \mathrm{SO}_{4}$ or adding further $\mathrm{SO}_{4}{ }^{2-}$. When packed suspensions of bacteria grown in $\mathrm{FeSO}_{4}$ medium (sulphate bacteria) were diluted in 3.2 $\mathrm{mm}-\mathrm{HCl}$ at $\mathrm{o}^{\circ} \mathrm{C}$ instead of room temperature, the bacteria (chloride bacteria) displayed little or no oxidation of iron as $\mathrm{FeCl}_{2}$ but responded strongly on addition of $\mathrm{SO}_{4}{ }^{2-}$ or $\mathrm{SeO}_{4}{ }^{2-}$ (Fig. $2 b$ ). These chloride bacteria maintained their activity in the absence of substrate at $0{ }^{\circ} \mathrm{C}$ but, unlike the sulphate bacteria, steadily lost activity at room temperature.

The two types of bacteria differed in the specificity of their response to added anions. The chloride bacteria required $\mathrm{SO}_{4}{ }^{2-}$ or $\mathrm{SeO}_{4}{ }^{2-}$ to oxidize $\mathrm{Fe}^{2+}$; all other anions tested were inactive (Table 3). However, the iron-oxidizing activity of sulphate bacteria was stimulated by several anions, including $\mathrm{PO}_{4}{ }^{3-}, \mathrm{AsO}_{4}{ }^{3-}, \mathrm{WO}_{4}{ }^{2-}$ and $\mathrm{TeO}_{4}{ }^{2-}$. The iron-oxidizing activity of chloride bacteria was enhanced by those anions only if $\mathrm{SO}_{4}{ }^{2-}$ or $\mathrm{SeO}_{4}{ }^{2-}$ was also added.

The conversion of sulphate bacteria to chloride bacteria is not simply a result of dilution of free sulphate in suspensions, since when sulphate bacteria were diluted or washed in distilled water, the specificity of their response to the addition of anions was unchanged (Fig. $2 c$ ). This suggests that at low temperatures $\mathrm{Cl}^{-}$ions reversibly displace bound $\mathrm{SO}_{4}{ }^{2-}$ from loci requisite for iron-oxidizing activity, but at higher temperatures the displacement of $\mathrm{SO}_{4}^{2-}$ leads to further irreversible changes. 


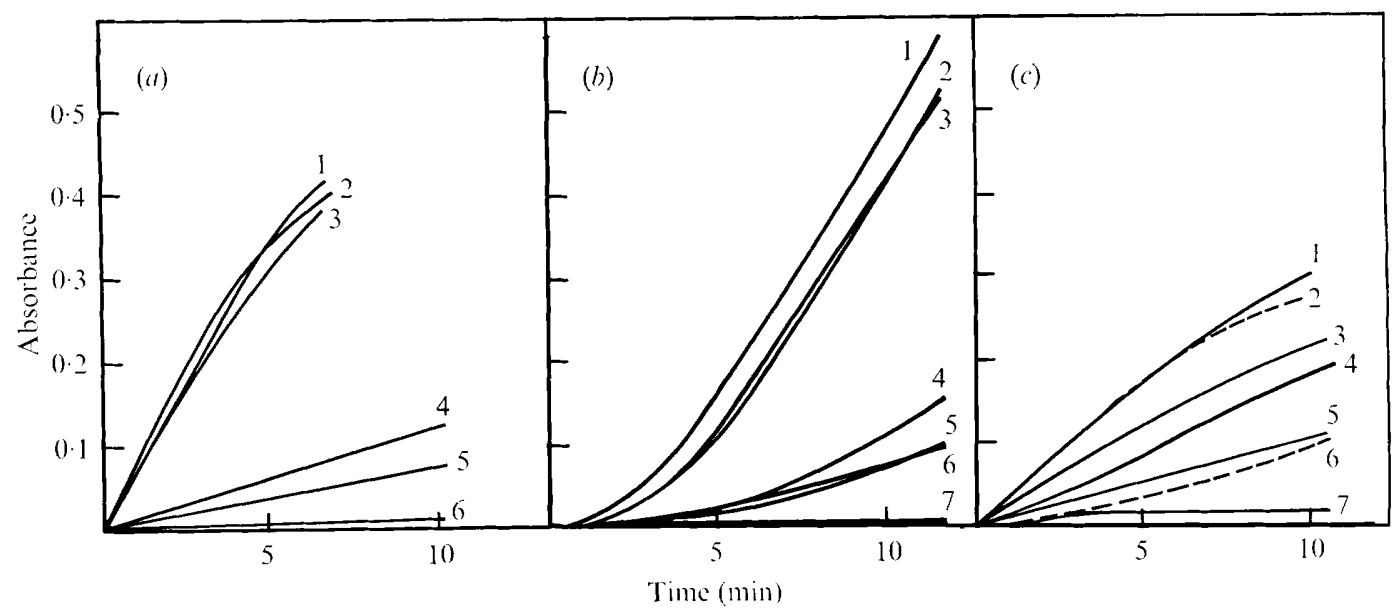

Fig. 2. Effect of the anionic environment on the formation of $\mathrm{Fe}^{3+}$ by $T$. ferrooxidans. $\mathrm{Fe}^{3+}$ formation was measured continuously by the increase in $E_{303}$ at room temperature. All solutions were adjusted to $\mathrm{pH} 2.5$ with $\mathrm{HCl}$ or $\mathrm{H}_{2} \mathrm{SO}_{4}$ as appropriate.

(a) Inactivation of bacteria by $\mathrm{Cl}^{-}$at room temperature. Bacteria were diluted $\mathrm{I}: \mathrm{IO}$ in $3.2 \mathrm{~mm}-$

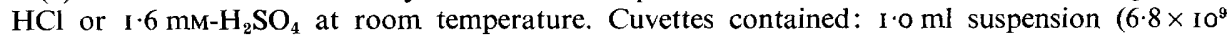
bacteria $\mathrm{ml}^{-1}$ ), I.0 $\mathrm{ml} \mathrm{I} \cdot 0 \mathrm{~mm}-\mathrm{Fe}^{2+}$ substrate and $\mathrm{I} \cdot 0 \mathrm{ml} 3.2 \mathrm{~mm}-\mathrm{HCl}$ or $\mathrm{I} \cdot 6 \mathrm{~mm}-\mathrm{H}_{2} \mathrm{SO}_{4}$. (I) $\mathrm{FeSO}_{4}$ substrate, bacteria added $130 \mathrm{~min}$ after dilution in $\mathrm{H}_{2} \mathrm{SO}_{4} ;(2) \mathrm{FeSO}_{4}$, immediately after dilution in $\mathrm{H}_{2} \mathrm{SO}_{4}$; (3) $\mathrm{FeSO}_{4}$, immediately after dilution in $\mathrm{HCl}$, or $\mathrm{FeCl}_{2}$, immediately after dilution in $\mathrm{H}_{2} \mathrm{SO}_{4}$; (4) $\mathrm{FeCl}_{2}$, immediately after dilution in $\mathrm{HCl}$; (5) $\mathrm{FeSO}_{4}$, I45 min after dilution in $\mathrm{HCl}$; (6) $\mathrm{FeCl}_{2}$, 60 min after dilution in $\mathrm{HCl}$.

(b) Effect of various anions on the activity of bacteria diluted in $\mathrm{HCl}$ at $0^{\circ} \mathrm{C}$. Cuvettes contained: $0.5 \mathrm{ml}$ bacterial suspension diluted $\mathrm{I}: 10$ in $3.2 \mathrm{mM}-\mathrm{HCl}, \mathrm{I} \cdot 0 \mathrm{ml} \mathrm{I} \cdot 0 \mathrm{~mm}-\mathrm{FeCl}_{2}$ and one of the

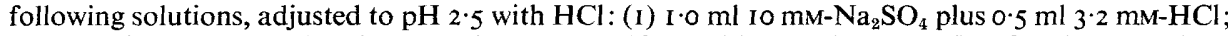

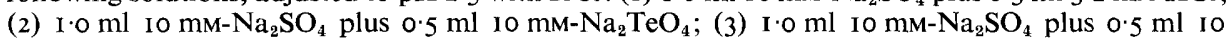

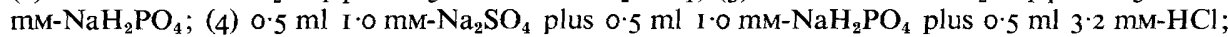
(5) $0.5 \mathrm{ml} \mathrm{r} \cdot 0 \mathrm{mM}-\mathrm{Na}_{2} \mathrm{SO}_{4}$ plus $\mathrm{I} \cdot 0 \mathrm{ml} 3.2 \mathrm{~mm}-\mathrm{HCl}$, bacteria added immediately after dilution; (6)

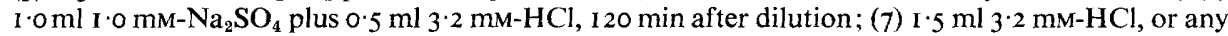
of the following (where necessary made up to $1.5 \mathrm{ml}$ with $3.2 \mathrm{~mm}-\mathrm{HCl}$ ): $0.5 \mathrm{ml} 10 \mathrm{~mm}-\mathrm{Na}_{2} \mathrm{TeO}_{4}$;

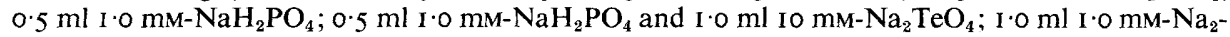

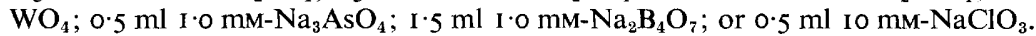

(c) Activity of bacteria diluted in $\mathrm{H}_{2} \mathrm{O}$ at $\mathrm{O}^{\circ} \mathrm{C}$. Cuvettes contained: $\mathrm{I} \cdot \mathrm{O}$ ml bacterial suspension diluted $\mathrm{I}: 20$ in $\mathrm{H}_{2} \mathrm{O}$ at ${ }^{\circ}{ }^{\circ} \mathrm{C}, \mathrm{I} \cdot 0 \mathrm{ml} \mathrm{I} \cdot 0 \mathrm{~mm}^{-\mathrm{FeCl}_{2}}$ and $\mathrm{I} \cdot 0 \mathrm{ml}$ of one of the following solutions, adjusted to $\mathrm{pH} 2.5$ with $\mathrm{HCl}$ : (1) I. $0 \mathrm{mM}^{-N_{2}} \mathrm{SO}_{4}$, bacteria added $15 \mathrm{~min}$ after dilution; (2) I $\cdot 0 \mathrm{~mm}$ $\mathrm{Na}_{2} \mathrm{SO}_{4}$, I $20 \mathrm{~min}$ after dilution; (3) $\mathrm{I} \cdot 0 \mathrm{mM}-\mathrm{Na}_{2} \mathrm{SeO}_{4}, 30 \mathrm{~min}$ after dilution; (4) I $0 \mathrm{~mm}-\mathrm{Na}_{2} \mathrm{TeO}_{4}$, $45 \mathrm{~min}$ after dilution; (5) $3.2 \mathrm{mM}-\mathrm{HCl}$, immediately after dilution; (6) $3.2 \mathrm{mM}-\mathrm{HCl}$, I05 min after dilution; (7) $\mathrm{I} \cdot \mathrm{O} \mathrm{mm}-\mathrm{Na}_{2} \mathrm{MoO}_{4}, 70 \mathrm{~min}$ after dilution.

\section{DISCUSSION}

In several biochemical systems, $\mathrm{SO}_{4}{ }^{2-}$ and $\mathrm{SeO}_{4}{ }^{2-}$ have similar activity indicating that the enzymes involved do not distinguish between these anions (Shrift, I958). Their identical behaviour in relation to iron oxidation could stem from close correspondence in the properties of their iron complexes. Thus, the reported stability constant $K_{1}$ at $25{ }^{\circ} \mathrm{C}$ for the sulphate complex of $\mathrm{Fe}^{2+}$ is $\mathrm{IO}$ and for the selenate complex is I 2 under the same conditions (Wells $\&$ Salam, I968). By contrast, $K_{1}$ for the chloride complex is less than 0.5 and for the $\mathrm{HPO}_{4}{ }^{2-}$ complex is $1 \cdot 5 \times 10^{7}$ (Sillen \& Martell, 197I). If the rate of iron oxidation were dependent on the concentration of a sulphate complex of $\mathrm{Fe}^{2+}$, inhibition due to complex formation by other anions should depend on the stability constants of the competing complexes. However, this is not the case; some anions which form weak complexes $\left(\mathrm{Cl}^{-}\right)$are inhibitory but those which form strong complexes $\left(\mathrm{HPO}_{4}{ }^{2-}\right)$ stimulate oxidation if $\mathrm{SO}_{4}{ }^{2-}$ or $\mathrm{SeO}_{4}{ }^{2-}$ is present.

Nearly all of the inorganic ligands stabilize the oxidized cationic species more strongly than 


\section{Table 3. Effects of various anions on the oxidation of $\mathrm{Fe}^{2+}$ by suspensions of T. ferrooxidans}

Reaction mixtures contained bacterial suspension diluted in water or $3.2 \mathrm{~mm}-\mathrm{HCl}, \mathrm{I} \mathrm{mM}-\mathrm{FeCl}_{2}$ and the anion indicated (as the sodium salt) at a final concentration of I mM. Results are expressed as the rate of increase in $E_{304}$ relative to that with $\mathrm{SO}_{4}{ }^{2-}$ as the added anion.

\begin{tabular}{|c|c|c|}
\hline \multirow[b]{2}{*}{ Anion added } & \multicolumn{2}{|c|}{ Relative rate of $E_{304}$ increase } \\
\hline & $\begin{array}{l}\text { Bacteria diluted } \\
\text { in } \mathrm{H}_{2} \mathrm{O}\end{array}$ & $\begin{array}{c}\text { Bacteria diluted } \\
\text { in } \mathrm{HCl}\end{array}$ \\
\hline None & $3 I \cdot 7$ & 0.0 \\
\hline $\mathrm{Cl}^{-}$ & $33 \cdot 5$ & 0.0 \\
\hline $\mathrm{Br}^{-}$ & 0.0 & 0.0 \\
\hline $\mathrm{NO}_{3}^{-}$ & 0.0 & 0.0 \\
\hline $\mathrm{SO}_{4}^{2-}$ & $100 \cdot 0$ & $100 \cdot 0$ \\
\hline $\mathrm{SeO}_{4}{ }^{2-}$ & $70 \cdot 0$ & 83.4 \\
\hline $\mathrm{TeO}_{4}{ }^{2-}$ & $60 \cdot 0$ & 0.0 \\
\hline $\mathrm{B}_{4} \mathrm{O}_{7}^{2-}$ & $4 I \cdot 4$ & 0.0 \\
\hline $\mathrm{ClO}_{3}^{-}$ & 19.9 & 0.0 \\
\hline $\mathrm{MoO}_{4}{ }^{2-}$ & 0.0 & 0.0 \\
\hline $\mathrm{WO}_{4}^{2-}$ & $50 \cdot 0$ & 0.0 \\
\hline $\mathrm{CrO}_{4}^{2-}$ & $*$ & $*$ \\
\hline $\mathrm{VO}_{4}{ }^{3-}$ & $*$ & $*$ \\
\hline $\mathrm{AsO}_{4}{ }^{3-}$ & $62 \cdot 2$ & 0.0 \\
\hline $\mathrm{PO}_{4}{ }^{3-}$ & $83 \cdot 2$ & 0.0 \\
\hline
\end{tabular}

* Slow chemical oxidation of $\mathrm{Fe}^{2+}$ occurred in the absence of bacteria, and there was no stimulation of abiotic oxidation in the presence of $T$. ferrooxidans.

the reduced species (Quagliano \& Rebertus, 1956). This would facilitate oxidation of $\mathrm{Fe}^{2+}$ by increasing the negative free energy change of the reaction. Although such properties of chloride and phosphate as ligands can account for their enhancement of the rate of chemical oxidation of $\mathrm{Fe}^{2+}$ (Wells \& Salam, 1968), the anionic requirement for biological oxidation by $T$. ferrooxidans is satisfied only by $\mathrm{SO}_{4}{ }^{2-}$ or $\mathrm{SeO}_{4}{ }^{2-}$. The anionic requirement for autotrophic growth, with $\mathrm{Fe}^{2+}$ as the sole source of utilizable energy, is satisfied only by $\mathrm{SO}_{4}{ }^{2-}$ since the $\mathrm{SeO}_{4}{ }^{2-}$ concentrations which sustain appreciable chemolithotrophic iron oxidation are toxic to growth of $T$. ferrooxidans.

The inability of other anions which form complexes with $\mathrm{Fe}^{2+}$ in acid solutions to replace $\mathrm{SO}_{4}{ }^{2-}$ does not rule out the possibility that complexing of the entering ferrous substrate or the leaving ferric product is necessary for the oxidation of iron by the bacteria. The oxidized iron product deposited by the activities of $T$. ferrooxidans is an aquated sulphate complex (jarosite) which differs from the form of iron precipitated after abiotic oxidation (Ivarson, I973). Nevertheless, a specific biochemical function of $\mathrm{SO}_{4}{ }^{2-}$ in iron oxidation is likely to be separate from its role as ligand for the metabolized iron species.

High concentrations of $\mathrm{SO}_{4}{ }^{2-}$, which inhibit oxygen uptake, do not concomitantly inhibit the formation of $\mathrm{Fe}^{3+}$ : this may indicate that $\mathrm{Fe}^{2+}$ oxidation can be partially uncoupled from the reduction of oxygen or that the stoicheiometry of iron oxidation and oxygen utilization can be altered toward increased efficiency of oxygen reduction (Steiner \& Lazaroff, 1974). Although Tuovinen et al. (1975) have reported that $\mathrm{SO}_{4}{ }^{2-}$ taken up during $\mathrm{Fe}^{2+}$ oxidation is, at least in part, converted to adenosine phosphosulphate, no evidence is yet available that this is part of an energy-generating mechanism, or that sulphate, in any form, is reduced during iron oxidation.

The requirement for sulphate in iron oxidation by $T$. ferrooxidans has been confirmed by investigations with whole cells (Schnaitman et al., 1969; Tuovinen et al., 197I) and with cell envelopes (Barvinchak, 1975). Cell-free studies of iron oxidase activity have not clearly shown a sulphate requirement, although chloride has been reported to inhibit $\mathrm{Fe}^{2+}$ :cytochrome $c$ reductase activity (Din, Suzuki \& Lees, 1967). The specificity of the anionic require- 
ment for iron oxidation by $T$. ferrooxidans agrees with the model proposed by Dugan \& Lundgren (1965) in which the ferrous substrate is bound as a sulphate and phosphate adduct to the bacterial cell envelope. Several earlier reports had indicated that the addition of phosphate stimulated oxygen uptake during $\mathrm{Fe}^{2+}$ oxidation (Lazaroff, I963; Beck \& Shafia, I964; Tuovinen et al., I97I). This is consistent with the present finding that $\mathrm{TeO}_{4}{ }^{2-}, \mathrm{WO}_{4}{ }^{2-}$, $\mathrm{AsO}_{4}{ }^{3-}$ or $\mathrm{PO}_{4}{ }^{3-}$ stimulate oxidation if $\mathrm{SO}_{4}{ }^{2-}$ or $\mathrm{SeO}_{4}{ }^{2-}$ is also present even though there is no absolute requirement for anions other than $\mathrm{SO}_{4}{ }^{2-}$ or $\mathrm{SeO}_{4}{ }^{2-}$.

The overall effect of the anionic environment can best be interpreted as the result of two different requirements for anions in the iron oxidation process. The first involves nonspecific iron complex formation in acid solution for which several anions including $\mathrm{SO}_{4}{ }^{2-}$ and $\mathrm{SeO}_{4}{ }^{2-}$ may serve as ligands. The second function specifically requires $\mathrm{SO}_{4}{ }^{2-}$ or $\mathrm{SeO}_{4}{ }^{2-}$ interaction with the bacteria for oxidation of the ferrous ion complex to occur.

\section{REFERENCES}

BARVINCHAK, G. (1975) Investigation of the mechanism of iron oxidation by cells and cell envelopes of Thiobacillus ferrooxidans. Thesis, Syracuse University, U.S.A.

Beck, J. V. \& Shafia, F. M. (1964). Effect of phosphate ion and 2,4-dinitrophenol on the activity of intact cells of Thiobacillus ferrooxidans. Journal of Bacteriology 88, 850-857.

DiN, G. A., Suzuki, I. \& LeES, H. (I967). Ferrous iron oxidation by Ferrobacillus ferrooxidans. Purification and properties of $\mathrm{Fe}^{2+}$ :cytochrome $c$ reductase. Canadian Journal of Biochemistry 45, I 523-I 546.

Dugan, P. R. \& Lundgren, D. G. (1965). Energy supply for the chemoautotroph Ferrobacillus ferrooxidans. Journal of Bacteriology 89, 825-834.

IVARSON, K. C. (1973). Microbiological formation of basic ferric sulfates. Canadian Journal of Soil Science 53, 315-323.

Kolthoff, I. M., Sandell, E. B., Meehan, E. J. \& BRUCKENSTEIN, S. (I969). Quantitative Chemical Analysis, pp. 1049-1062. Toronto: The Macmillan Co.

LAZAROFF, N. (1963). Sulfate requirement for iron oxidation by Thiobacillus ferrooxidans. Journal of Bacteriology 85, 78-83.

PICK, U. \& Avron, M. (I973). Inorganic sulfate and selenate as energy transfer inhibitors of photophosphorylation. Biochimica et biophysica acta 325, 297-303

Quagliano, J. V. \& Rebertus, R. L. (I956). Stabilization of valence states through coordination. In Chemistry of the Coordination Compounds, pp. 398-4I5. Edited by J. C. Bailar Jr. New York: Reinhold Publishing Corp.

Razzell, W. E. \& Trussel, P. C. (I963). Isolation and properties of an iron oxidizing Thiobacillus. Journal of Bacteriology 85, 595-603.

SchnattMan, C. A., KorCzynski, M. D. \& LundGREN, D. G. (I969). Kinetic studies of iron oxidation by whole cells of Ferrobacillus ferrooxidans. Journal of Bacteriology 99, 552-557.

ShrifT, A. (1958). Biological activities of selenium compounds. Botanical Review 24, 550-583.

Sillen, L. G. \& Martell, A. E. (I971). Stability Constants of Metal Ion Complexes, special publication no. 25. London: The Chemical Society.

Silverman, M. P. \& Lundgren, D. G. (I959). Studies on the chemoautotrophic iron bacterium Ferrobacillus ferrooxidans. I. An improved medium and a harvesting procedure for securing high cell yields. Journal of Bacteriology 77, 642-647.

StadtMan, T. C. (1974). Selenium biochemistry. Science, $183,915-92 \mathrm{I}$.

Steiner, M. R. \& LazarofF, N. (1974). Direct method for continuous determination of iron oxidation by autotrophic bacteria. Applied Microbiology 38, 872-88o.

Tuovinen, O. H., Niemella, S. I. \& GyllenberG, H. G. (I97I). Effect of mineral nutrients and organic substances on the development of Thiobacillus ferrooxidans. Biotechnology and Bioengineering $13,517-527$.

Tuovinen, O. H., Kelley, B. C. \& Nicholas, D. J. D. (1975). The uptake and assimilation of sulphate by Thiobacillus ferrooxidans. Archives of Microbiology 105, I23-I 27.

Wells, C. F. \& Salam, M. A. (I968). Complex formation between iron(II) and inorganic anions. Part 1I. The effect of oxyanions on the reaction of iron(II) with hydrogen peroxide. Journal of the Chemical Society $(A)$, 308-3I5. 